\title{
Direct Carotid-Cavernous Fistula with early drainage into inferior petrous sinus
}

\author{
Fístula Direta Carotídeo-Cavernosa com drenagem precoce \\ para seio petroso inferior
}

\section{Fístula carótido-cavernosa directa con drenaje temprano al seno petroso inferior}

Olavo Leite de Macêdo Neto ${ }^{1}$, Amanda Menezes Morgado², Rafael dos Santos Araujo ${ }^{3}$, José Silva Souza ${ }^{4}$, Ana Carla da Silva Mendes ${ }^{5}$, José Correia Saraiva Júnior ${ }^{6}$

\begin{abstract}
1.Medical student, Faculdade Medicina Estácio de Juazeiro do Norte, Juazeiro do Norte-CE, Brazil. https://orcid.org/0000-0001-8645-4633

2.Medical student, Faculdade Medicina Estácio de Juazeiro do Norte, Juazeiro do Norte-CE, Brazil. https://orcid.org/0000-0002-0661-7875

3. Medical student, Faculdade Medicina Estácio de Juazeiro do Norte, Juazeiro do Norte-CE, Brazil. https://orcid.org/0000-0002-9987-2022

4.Medical student, Faculdade Medicina Estácio de Juazeiro do Norte, Juazeiro do Norte-CE, Brazil. https://orcid.org/0000-0002-4229-2625

5.Medical student, Faculdade Medicina Estácio de Juazeiro do Norte, Juazeiro do Norte-CE, Brazil. https://orcid.org/0000-0001-6850-9709

6.Doctor, Neurosurgeon, Universidade Federal do Vale do São Francisco (UNIVASF), Barbalha-CE, Brazil. https://orcid.org/0000-0001-7072-9874
\end{abstract}

\section{Resumo}

As fístulas carótido-cavernosas (FCC) podem ser classificadas em diretas (Barrow A) e indiretas. As diretas são aquelas onde há uma comunicação entre a artéria carótida interna $(A C I)$ e o seio cavernoso, geralmente decorrente de eventos traumáticos e rotura aneurismática. No caso relatado, é descrita uma paciente do sexo feminino, de 51 anos, diagnosticada com hemorragia subaracnóidea, via tomografia computadorizada de crânio. Após submissão a uma arteriografia cerebral, foi identificado um aneurisma grande dissecante na carótida interna direita e uma FCC direta com drenagem precoce para a veia oftálmica e seio petroso inferior, manifestando paralisia do III par craniano.

Unitermos. Fístula carótido-cavernosa; Aneurisma; Artéria carótida interna; Cefaleia

\begin{abstract}
Carotid-cavernous fistulas (CCF) are classified in direct (Barrow A) and indirect. The direct comunication between the cavernous segment of the internal carotid artery and the cavernous sinus defines direct CCF. In the present case, is described a 51-year-old female patient, diagnosed with subarachnoid hemorrhage through head tomography. The patient underwent an agiographic study, wen was identified a large dissecant aneurysm in the right internal carotid artery and a direct CCF with early drainage into the ophthalmic vein and inferior petrous sinus, manifesting paralysis of the third cranial nerve.
\end{abstract}

Keywords. Carotid-cavernous fistulas; Aneurysm; Internal carotid artery; Cephalgia

\section{Resumen}

Las fístulas carótido-cavernosas (FCC) se pueden clasificar en directas (Barrow A) e indirectas. Las directas son aquellas donde existe una comunicación entre la arteria carótida interna $(\mathrm{ACI})$ y el seno cavernoso, generalmente como resultado de eventos traumáticos y ruptura aneurismática. En el caso reportado, se describe a una paciente de 51 años, diagnosticada de hemorragia subaracnoidea, mediante tomografía computarizada de cráneo. Tras someterse a una arteriografía cerebral, se identificó un gran aneurisma disecante en la 
Research developed at Hospital Santo Antônio, Barbalha-CE, Brazil.

\section{INTRODUCTION}

Ehlers-Danlos syndrome and internal carotid artery (ICA) aneurysms, as well as traumatisms, are among the causes for direct carotid-cavernous fistula (CCF), which is characterized by an abnormal communication between the ICA and the cavernous sinus. Patients may present with eyelid edema, diplopia, and visual impairment along with other signs/symptoms. Diagnosis and treatment are based on angiographic study and Trans-arterial embolization, respectively. The present study aims to report a case of direct CCF, type Barrow A, associating clinical aspects of its pathology.

\section{CASE REPORT}

The churrent project was submitted and approved by Faculdade de Medicina Estácio de Juazeiro do Norte's ethics and research committe by the Certificate of Presentation of Ethical Appreciation (CPEA) number 30929420.1 .0000 .8074$.

A 51-year-old female, smoker, presented with complaints of a sudden pulsatile headache in the right 
temple region. A head Computerized tomography (CT) was performed demonstrating a diffuse subarachnoid hemorrhage as a result from a ruptured brain aneurysm, which was confirmed by magnetic resonance (MRI). Within a few days of symptoms onset, the patient reported worsened headache associated with right upper eyelid edema and diplopia. In addition, a month before admission, she suffered a fall from the standing heigh with loss of consciousness, headaches and nausea are often since then. Neurologic examination showed right direct and consensual pupillary light reflexes both impaired (Figure 1), preserved visual function, central hemiparesis, and hypoesthesia in right temple region. Muscle strength impairment on the left side. The patient was transferred and an arteriographic study was indicated showing a large aneurysm arising from the internal carotid artery and a direct carotid-cavernous fistula (Barrow A) with early drainage into the ophthalmic vein and inferior petrous sinus.

\section{DISCUSSION}

Carotid-cavernous fistula can be further classified into specific types, such as direct (Barrow A) - which represents the greatest percentage, characterized by particular intense flow, and its cause is founded in traumatic events (75\%), including microtrauma, and ICA aneurysm rupture (25\%), most of the times placed in the distal segment - and indirect - low flow type of fistula, arising spontaneously from dural arteriovenous malformations (DAVMs) ${ }^{1-3}$. 

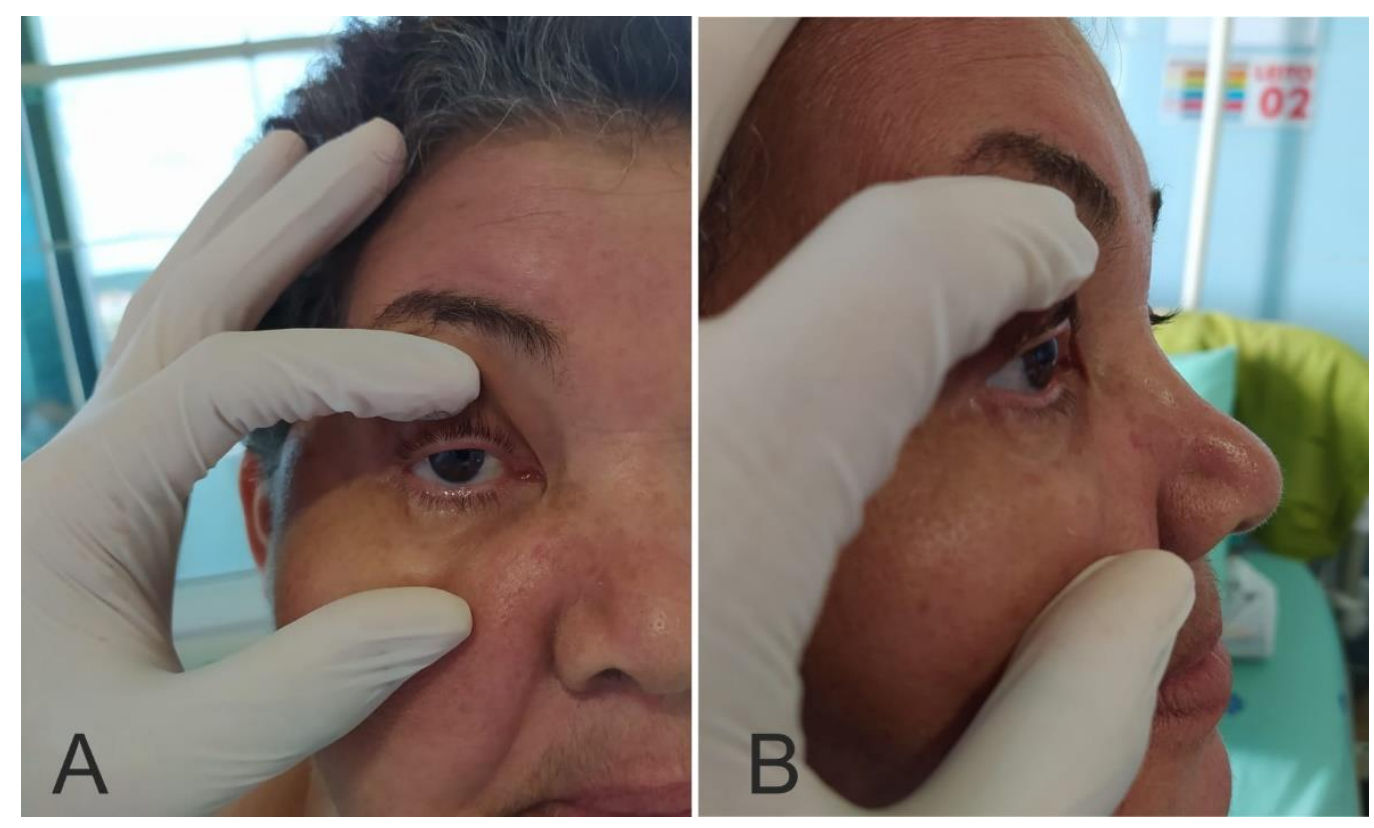

In matters of symptomatology, the classical presentation is composed by proptosis, ocular bruit and quemosis $^{2}$. Furthermore, visual impairment, orbital pain, and cranial nerve disturbance, specially the fifth one, are non-rare features of this pathology 3,4 . It is decisive to impose an early treatment, intending to avoid permanent complications, to cite irreversible ocular lesions, once the arterial pressure is transferred to the cavernous sinus, leading to an increased flow and venous dilatation. The result is venous engorgement with progressive intensifying of intraocular pressure, therefore allowing damage of the retina and extraocular muscles, which is worsened by cranial nerves compression ${ }^{5,6}$.

Targeting a correct diagnosis, angiographic studies are imperative ${ }^{1,2,4}$. However, head CT may show a cavernous 
sinus dilatation and MRI enables to observe cortex, cerebellum, and brainstem involvement ${ }^{8}$. Carotid Doppler ultrasonography is useful as a non-invasive method of exam, recognizing the hemodynamic conditions of the fistula ${ }^{4,7}$.

Figure 2. Right ICA aneurysm and direct CCF with early drainage into the ophthalmic vein and inferior petrous sinus observed through 3D digital arteriography.

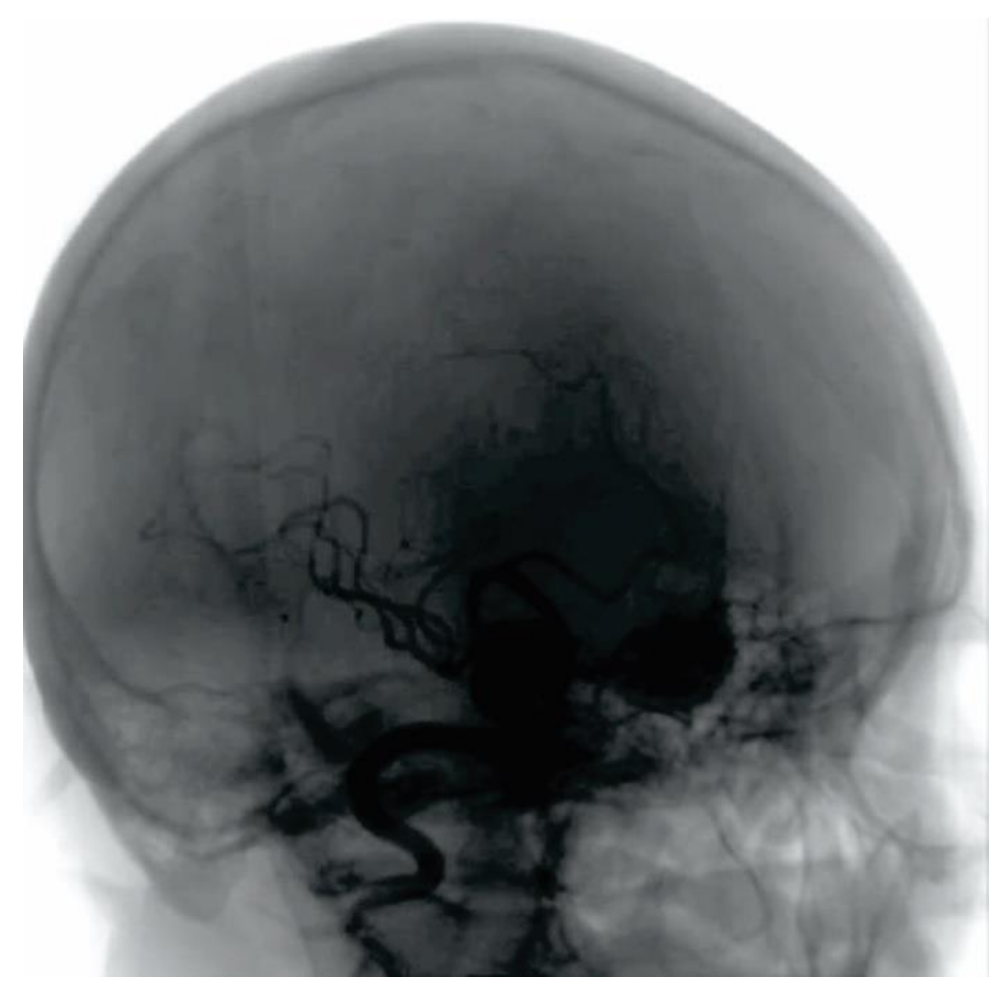


Figure 3. Right ICA digital arteriography showing a large dissectum aneurysm, $16 \mathrm{~mm} \times 15 \mathrm{~mm}$, and direct CCF.

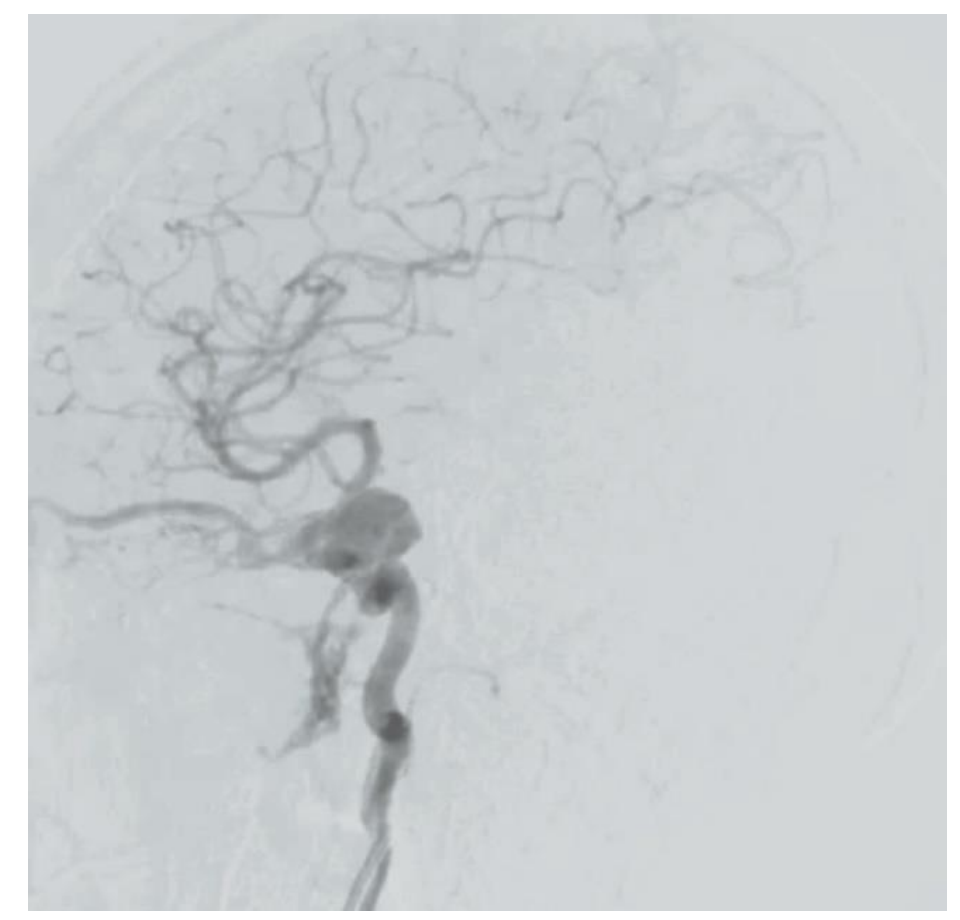

Endovascular repair is the standard choice for treatment 2,8 , particularly aiming to avoid ensuing eyeball permanent damage. The speed of the blood flow through the fistula, along with other features, such as patency of the circle of Willis, are determining factor to guide treatment choice. Transarterial approach via ICA is used most times as a pattern. It is crucial to consider endoluminal reconstruction in severe patients avoiding embolic events.

An early diagnosis is highlighted as fundamental moment as well as the exclusion of other differential diagnosis improving patient outcome and reducing various serious complications: orbital cellulitis, graves 
exophthalmia, orbital pseudotumor, cavernous sinus thrombophlebitis, hemangiomas, malign neoplasia (lymphoma, rhabdomyosarcoma, pulmonary metastasis), retrobulbar hemorrhage secondary to trauma7,9,10. Decreased visual function, late diagnosis, posterior drainage, multiples procedures are main factors in favor for a poor clinical condition. Moreover, diplopia as a present symptom in the moment of diagnosis is a sign of a bad prognosis $^{1,3}$.

The patient was referred for treatment, in which she underwent endovascular repair with microcoils and intracranial stent, which occurred without any complications. When she was discharged, dual antithrombotic therapy was prescribed: ASA $100 \mathrm{mg} /$ day indefinitely and clopidogrel $75 \mathrm{mg}$ for 90 days, due to the risk of in-stent thrombosis and serious and irreversible complications. In this context, the patient evolved with a decrease in global ophthalmoplegia, ptosis and facial paresis, being followed up at the neurology clinic every 3 months.

The therapeutic modality is evaluated through angiographic evaluations. The surgical option of ligation of the common carotid artery is used when it is not possible to perform endovascular repair or when there are failures in it $^{11,12}$.

The main therapy nowadays is endovascular therapy, a procedure to which the patient was submitted. Treatment by isolated microcoil embolization is associated with the 
risk of recanalization and distal migration of the coil leading to ischemic stroke (iCVA), the placement of the stent prevents its distal migration. Stent placement preserves the flow in the internal carotid artery, is related to a lower risk of (iCVA), however, it presents a risk of dissection and rupture ${ }^{11,12}$.

\section{CONCLUSION}

The present case evidenced a direct CCF diagnosed by radiology exams, highlighting the angiographic study, and suspected after onset of ocular symptomatology supported by venous flow change in the ophthalmic vein and the inferior sinus petrous, associated with unusual manifestation such as palsy pf the third cranial nerve. It is crucial to determine early diagnosis and effective treatment, considering its insidious course and potential for severe complications.

\section{REREFÊNCIAS}

1.Torres M, Rubio W, Conde G, Polo L, Padilla K, Gamero J, et al. Síntomas neurológicos de fístula carotídeo cavernosa: reporte de caso. Acta Neurol Colomb 2017;33:274-8. http://dx.doi.org/10.22379/24224022167

2. Kohli GS, Patel BC. CarotidCavernous Fistula (internet).2019 (Acess in: 31 mar. 2020). Available from:

https://www.ncbi.nlm.nih.gov/books/NBK535409/

3.Calle MI, Hernández OH. Fístula carótido-cavernosa espontánea bilateral: reporte de caso y revisión de la literatura. Acta Colomb Cuid Inten 2016;16:23-30. https://doi.org/10.1016/j.acci.2015.10.002

4.Borba R, Sonda I, Dini LI, Calcagnotto FN, Marchett N, Cobalchini PC. Fístula carótido-cavernosa com epistaxe letal: relato de caso. Arq Neuropsiqu 2001;59:276-9.

https://doi.org/10.1590/S0004282X2001000200027

5.Braga MF, Melo PM. Fístulas Carótido Cavernosas. Guias de Medicina Ambulatorial e Hospitalar- UNIFESP/Escola Paulista de 
Medicina - Neurocirurgia. São Paulo: Manole; 2005, cap 42, p. 40310.

6.de Siqueira SB, de Siqueira CM, Landeiro JA, Junior OM. Tratamento endovascular das fístulas carótido-cavernosas. Arq Bras Neurocirurg 2006;25:17-22.

7.Vilela MA. Carotid-cavernous fistula. Rev Bras Oftalmol 2013;72:70-5.

https://doi.org/10.1590/S0034-

\section{5}

8.Sur S, Menaker SA, Alvarez C, Chen S, Shah SS, Peterson EC, et al. Multimodal Management of Carotid-Cavernous Fistulas. World Neurosurg 2020;133:796-803.

http://dx.doi.org/10.1016/j.wneu.2019.10.004

9.de Jesús Batún-Garrido JA, Hernández-Núñez É. Fístula carótidocavernosa. Med Int Méx 2014;30:607-12.

https://www.medigraphic.com/pdfs/medintmex/mim-

2014/mim145n.pdf

10.Charlin RE, Pacheco PB, Villarroel FW, Urbina FA. Carotid cavernous fistula: the importance of its opportune diagnosis and treatment to prevent blindness. Rev Med Chile 20041;132:1221-6. https://doi.org/10.4067/s0034-98872004001000010

11. Hou K, Li G, Luan T, Xu K, Yu J. Endovascular treatment of the cavernous sinus dural arteriovenous fistula: current status and considerationsions. Int J Med Sci 2020;17:1121-30. https://doi.org/10.7150/ijms.45210

12.Korkmazer B, Kocak B, Tureci E, Islak C, Kocer N, Kizilkilic O. Endovascular treatment of carotid cavernous sinus fistula: A systematic review. World J Radiol 2013;5:143-55.

https://doi.org/10.4329/wjr.v5.i4.143 